Société d'histoire de la révolution de 1848 et des

révolutions du XIXe siècle

16 | 1998

1848. Un modèle politique à l'épreuve

\title{
Les vétérans de la Seconde république : mémoires et héritages (fin XIXe-début XXe siècles)
}

\author{
Jean El Gammal
}

\section{(Q) OpenEdition \\ Journals}

Electronic version

URL: http://journals.openedition.org/rh19/132

DOI: $10.4000 /$ rh 19.132

ISSN: $1777-5329$

\section{Publisher}

La Société de 1848

\section{Printed version}

Date of publication: 1 June 1998

ISSN: 1265-1354

\section{Electronic reference}

Jean El Gammal, «Les vétérans de la Seconde république : mémoires et héritages (fin XIXe-début XXe siècles) », Revue d'histoire du XIXe siècle [Online], 16 | 1998, Online since 10 September 2008, connection on 20 April 2019. URL : http://journals.openedition.org/rh19/132; DOI : 10.4000/rh19.132

This text was automatically generated on 20 April 2019

Tous droits réservés 


\title{
Les vétérans de la Seconde république : mémoires et héritages (fin XIXe-début XXe siècles)
}

\author{
Jean El Gammal
}

\section{ABSTRACTS}

Echoing the upheavals of the middle of the XIXth century the article studies the role and place of the veterans of the Second Republic, mainly the Members of Parliament, at the end of the century. They were a group whose number was finally fairly limited and whose political convictions varied immensely. The 1848 veterans expressed themselves very differently and very seldom behaved as "vets". They were paid very discreet homage by the representatives of the younger Republican generations. Nevertheless there still remains visible the setting up of dynasties of Republicans which implements a political language that feeds the idea of Republic.

En écho lointain des bouleversements du milieu du XIXe siècle, l'article étudie le rôle et la place, à la fin du siècle, des vétérans de la Seconde République, surtout des parlementaires. Groupe finalement assez restreint, aux convictions politiques fort diverses, les anciens de 1848 s'expriment inégalement et se comportent assez peu en " anciens combattants ". Les hommages qui leur sont rendus par les représentants des plus jeunes générations républicaines sont plutôt discrets. Reste toutefois visible l'établissement de dynasties de républicains, mettant en œuvre un langage politique qui nourrit l'idée de république. 
INDEX

Mots-clés: Vétérans, Seconde République 